\section{Hvordan skape bedre tilgang til helsetjenester i verden?}

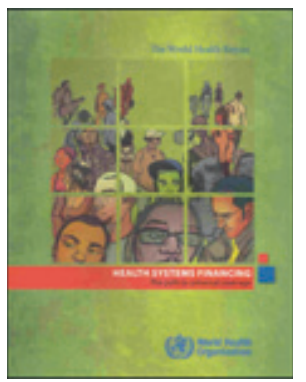

\section{Verdens helseorganisasjon}

The world health report -

Health systems financing

The path to universal coverage. 106 s, tab, ill

Genève: WHO, 2010. Pris CHF 40

ISBN 978-92-4-156402-1

http://www.who.int/whr/2010/en/index.html

Denne rapporten fra Verdens helseorganisasjon gir en nyttig oversikt over de store globale utfordringer knyttet til finansiering av helsetjenester. Den argumenterer overbevisende for «universal coverage» som vanskelig lar seg oversette direkte («full dekning» gir mer assosiasjon til mobilnett). Kjernen er at alle mennesker skal gis tilgang til helsetjenester.

I første kapittel illustreres sakens kjerne i en tredimensjonal figur: Hvor stor andel av befolkningen er dekket; hvor stor andel av kostnadene er dekket; hvor stor andel av tjenestene er dekket. Ingen helsesystemer har full dekning langs alle dimensjoner. I Norge er i prinsippet hele befolkningen dekket, men ikke alle kostnadene er dekket (egenandeler på flere tjenester), og heller ikke alle tjenester (f.eks. reseptfrie legemidler). Desto lavere andeler de tilgjengelige offentlige eller private forsikringsfond kan finansiere, desto større underfinansiering av helsetjenester, m.a.o. desto lenger er vi fra «full dekning».

Mens disse tre dimensjonene gir en nyttig illustrasjon, savner jeg en diskusjon av at to dimensjoner henger sammen: Når folks betalingsevne er ulikt fordelt (den er totalt fraværende for store grupper i fattige land), vil jo økende egenandeler tilsvarende redusere andelen av befolkningen som er dekket. Altså, $100 \%$ av befolkningen kan ikke få dekning uten at $100 \%$ av kostnadene er dekket. Den store utfordringen ligger i den tredje dimensjonen, nemlig hvilke tjenester som skal tilbys gratis. Denne prioriteringsutfordringen er grunnleggende universell - den møter alle land uavhengig av hvor stort helsebudsjettet er.

Boken har treffende kapitteloverskrifter som «More money for health» og «More health for the money». Om det første argumenteres det for «compulsory contribution»: mer penger til helsesektoren nødvendiggjør tvungen finansiering, enten gjennom generelle skatter eller øremerkede helseskatter. Her savnes noen oversiktlige tabeller over den relative betydningen av ulike finansieringskilder i verden. Privat helseforsikring utgjør kun $8 \%$ av verdens helsetjenestefinansiering, direkte pasientbetaling utgjør $33 \%$ globalt, men langt mer i den fattige del av verden. De resterende $59 \%$ er sosiale forsikringer, herunder skatter. Det er interessant å merke seg at desto rikere et land er, desto mer baseres finansiering av helsetjenester på slik «compulsory prepayment» (1).

I kapitlet om «mer helse for pengene» drøftes ulike typer ineffektivitet og argumenteres det for en rekke tiltak, bl.a. mer bruk av billige ikke-patenterte legemidler, strengere kliniske retningslinjer og bedre arbeidsdeling mellom helseprofesjoner. Selv om ulike typer ineffektivitet varierer, anslår rapporten at det samlede potensialet for effektivitetsforbedring ligger i området $20-40 \%$ av helsetjenestekostnadene, både for høyinntekts-, middelinntekts- og lavinntektsland. Anslagene kan fortone seg litt løse, men det er liten grunn til å tro at ikke også Norge, som bruker nest mest i verden på helsetjenester per innbygger, har betydelige effektivitetspotensialer i sitt helsevesen. Vi bør nok derfor være mer opptatt av «More health for the money» enn «More money for health»!
Boken kan anbefales for praktikere og studenter med interesse for internasjonal helse. Som kjent er det lett å anbefale noe som er gratis, og denne ligger bare noen tastetrykk inne på WHOs hjemmeside. Litt forkunnskaper i helseøkonomi og helsepolitikk vil nok være en fordel, men også her finnes det egnede innføringsbøker. De er ikke gratis, men mange er verdt pengene.

\section{Jan Abel Olsen}

nstitutt for samfunnsmedisin

Universitetet i Tromsø

\section{Litteratur}

1. World Health Statistics. www.who.int/whosis/whostat/en/index.html (2.5.2011)

\section{Den profesjonelle taushet}

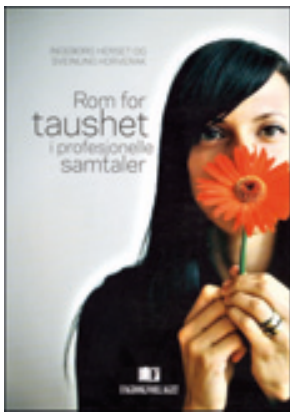

Ingeborg Herset, Sveinung Horverak Rom for taushet i profesjonelle samtaler 145 s. Bergen: Fagbokforlaget, 2011. Pris NOK 229 ISBN 978-82-450-0961-3

Å håndtere pasienters taushet og time sin egen taushet er en utfordring for alle som skal bli leger. Før de har fătt god opplæring $\mathrm{i}$ å kommunisere med pasienter, synes mange medisinstudenter at det er pinlig når pasienten blir taus, og er selv redd for å holde munn noen sekunder. Tryggheten kommer når de oppdager hvor viktig og konstruktiv dialogen med pasienten kan bli om de lar den tause pasient i fred en stund, og tillater seg selv også å tenke seg om i ro og fred. Boken er først og fremst rettet mot utdanningen av høyskolens helsepersonell, men har også gode poenger for medisinstudenter og unge leger.

Forfatterne har sin kliniske erfaring fra barnevern og sosialtjenester i kommunene. De starter med en mer teoretisk gjennomgang av former for taushet, innhold i taushet, taushetens vesen og ulike vurderinger av god og dårlig taushet. I neste del drøftes ulike strategier som behandleren kan bruke i forhold til forskjellige klienters ulike former for taushet. Og i et avsluttende kapittel argumenteres det for betydningen av at hjelperen kan være taus sammen med sin klient når viktige følelser derved kan deles. Boken avgrenser seg fra bruk av taushet som terapeutisk virkemiddel, og det blir henvist til psykoterapilitteratur.

Dette er en lettlest bok. En del av den er basert på en masteroppgave, og det preger deler av språket som kan bli noe omstendelig og med gjentakelser. Eksemplene og de kliniske vignetter er gode og instruktive, men bare noen få er fra sykepleiesektoren. Innholdet er er for elementært for leger med klinisk erfaring. Men medisinstudenter som spanderer et par timers lesning, kan nok plukke opp viktige ting.

\section{Per Vaglum}

Avdeling for medisinske atferdsfag

Universitetet i Oslo 